\title{
Entre o terror e o desbunde: A oposição aos governos militares brasileiros na visão de Carlinhos Oliveira em "Um novo animal na floresta" (1968-1981)
}

\author{
Between horror and mess: The oposition to military governments by \\ the view of Carlinhos de Oliveira at the book "Um novo animal na \\ floresta" (1968-1981)
}

\author{
Jean Carllo de Souza Silva \\ Márcia Pereira da Silva**
}

RESUMO

O artigo aborda o livro Um novo animal da floresta, romance de autoria do cronista José Carlos Oliveira. Por meio das aventuras da personagem Carlinhos, o autor, de mesmo nome, problematiza a tensão de pessoas que viveram as décadas de 60 e 70 do século XX em ambientes propícios para a adesão à guerrilha, mas optaram pela legalidade e por não integrarem grupos e manifestações nem de esquerda, nem de direita.

Palavras-chave: Ditadura militar. Guerrilha. Romance. Cronista. Literatura.

\footnotetext{
* Graduado em Jornalismo, especialista em Metodologia e Didática do Ensino Superior pela Universidade do Estado de Minas Gerais. É mestrando em História (História Social) da Universidade Federal de Uberlância - UFU. Atualmente é professor dos cursos de Jornalismo e Publicidade e Propaganda da Universidade do Estado de Minas Gerais (UEMG) unidade de Passos, onde leciona as disciplinas de História Social dos Meios, Teorias da Interpretação e Tópicos Especiais em Publicidade e Propaganda.

** Tem Graduação (Licenciatura) em História e Mestrado em História Social pela UNESP - Campus de Franca, e Doutorado em Culturas Políticas pela Universidade Federal de Minas Gerais - UFMG. É professora de História Contemporanea do Curso de História da Unesp e docente do Programa de Pós-Graduação em História da mesma Instituição. Orienta Mestrado e Doutorado, tem projetos financiados de ensino, pesquisa e extensão. Publica textos relativos aos governos militares e experiências de exceção, bem como trabalhos sobre o ordenamento social urbano das primeiras décadas do Brasil republicano
} 


\section{ABSTRACT}

This article mentions the book named Um novo animal na floresta novel whose author is the chronicle writer José Carlos de Oliveira. By means of Carlinho's adventures, the author, called by the same name, wonders about the tension of some people who lived between the 60's and the 70's of the 20th century in environments which propitiated the support of guerrilha, but these one sopted not to be part of any group, nor left parties nor right-wing parties.

Keyword: Military dictatorship, Guerrilha, Novel, Chronicle, Writer, Literature.

É tempo de aflição e festa, entrelaçadas.

Carlinhos Oliveira, 1981

\section{Introdução}

Em 1981 o jornalista e literato José Carlos Oliveira lançou Um novo animal na floresta: romance bastardo. Nesse livro o autor trama, em uma narrativa construída ao estilo romance reportagem, as relações políticas e culturais do Brasil do final dos anos 1960 e início dos 70, período de recrudescimento do regime em vigor no país desde o golpe de 1964.

A voz narradora da personagem protagonista, o cronista Calinhos Oliveira, sobressai no romance. É ela a responsável por, de forma fragmentária, condição presente nas lacunas espaço temporais traduzidas na própria organização não-linear dos capítulos, narrar eventos que marcaram a história do país e conferir vida às personagens que afetaram a existência do protagonista e, podemos conjecturar, do autor do livro.

Sabemos que Um novo animal na floresta não foi um livro aclamado pela crítica literária ou um sucesso comercial na época do seu lançamento, e nem depois, a bem da verdade. Contudo, a voz narradora, a voz de Carlinhos Oliveira que muitas vezes se mostra desconexa e até delirante em alguns momentos, é um exemplo dos relatos atordoantes sobre o período dos governos militares.

Sobre o autor do romance é preciso dizer algumas palavras. José Carlos Oliveira foi cronista do Jornal do Brasil, função profissional e local social que o tornou célebre nos meios artísticos e intelectuais cariocas durante a segunda metade do século XX. Tendo nascido em Vitória em 1934 e morrido nessa mesma cidade em 1986, após décadas residindo no Rio de Janeiro, é flagrante em seus escritos que Oliveira pensava o mundo a partir do universo da zona sul carioca. Por ser um 
"animal" adaptado à floresta social de Ipanema fez desse microcosmo a ambientação da maioria dos seus escritos, inclusive em Um novo animal na floresta.

No início dos anos 60, José Carlos Oliveira escrevia crônicas para o Jornal do Brasil, mais de uma vez por semana, sobre quaisquer temas, periodicidade que não foi interrompida após o golpe de 1964. Durante esse período, em diversas crônicas, ele opôs-se ao governo, denunciando a censura às artes, a tortura, as ações da guerrilha urbana e a atmosfera de pânico e paranoia reinantes. Mas também abordou a revolução dos costumes, a pílula anticoncepcional, a minissaia, a nova estética - e ética - proposta pela tropicália de Caetano Veloso e Gilberto Gil.

Como cronista, Oliveira usou o espaço que tinha no jornal para criticar o governo, mas nunca se mostrou muito afinado com a esquerda que se autoproclamava socialista, tampouco entrou para o movimento guerrilheiro, o que motivou a pecha de nunca ter se posicionado de fato em relação à ditadura. No romance que escolhemos analisar neste artigo - Um novo animal na floresta - o autor, inclusive, trata da opção da personagem protagonista em não se alinhar com nenhuma ideologia do período (direita ou esquerda), embora tenha amigos de ambos os lados.

Embora Um novo animal na floresta seja um livro explicitamente ficcional, elementos como o fato da personagem central do romance dividir o mesmo nome, Carlinhos Oliveira, e a mesma profissão, cronista, do autor, não nos parece uma banalidade ou mero joguete literário. José Carlos borra intencionalmente as fronteiras entre a realidade histórica, passível de ser narrada por verossimilhança com o real e calcada em documentos considerados vestígios do passado, e a imaginação criadora, por pressuposto, livremente inventiva.

Nesse sentido, José Carlos operou o que Lucileide Cardoso (2012, p.137) apontou como uma característica presente em outros romances da mesma safra, a recuperação "do sujeito histórico em sua plenitude, revelando sentimentos, emoções e atitude dos participantes da luta armada" e outros agentes, ao sintetizar no ficcional o real e o imaginário.

Pensar a interface entre o vivido e a ficção em José Carlos de Oliveira foi tema do pesquisador José Irmo Gonring, em artigo sobre O Pavão desiludido, obra em que o autor afirma ter feito uma autobiografia. De acordo com Gonring (2012, p.13), José Carlos Oliveira, "ao buscar a verossimilhança total, um 'desenho lógico' perfeito, em suas obras 'autobiográficas', costurando causa e efeito, acaba por nos deixar também ao sabor da indecidibilidade, e indagamos: 'Foi mesmo assim?"'. Diante da questão, Gonring recorreu aos conceitos de "autoficção" e de "performance". Nesse sentido, Carlinhos (autor) se transforma em Carlinhos (narrador/personagem) rompendo, por um lado, com o compromisso de se manter fiel a autobiografia e, pelo outro, com a ficção.

Em Um novo animal na floresta, diferente de O Pavão desiludido, José Carlos Oliveira não afirma ter feito autobiografia, mas ficção. Assim, preferimos recorrer a Paul Ricoeur (2010, p.325) para quem os "acontecimentos contados numa narrativa de ficção são fatos passados para a voz 
narrativa, que podemos considerar aqui idêntica ao autor implicado, ou seja, a um disfarce fictício do autor real. Fala uma voz que narra o que, para ela, ocorreu". Apontamos para uma espécie de proposição social que precede a obra ficcional, estabelecendo entre leitor e autor a crença no caráter de passado dos acontecimentos narrados pela voz narrativa. A intriga presente na operação ficcional do romance, compartilhada, aliás, pela escrita da História, também trabalha com o verossímil, em especial na literatura "realista". Mas, segundo Ricoeur, quando o romance ficcional deixa de ser imitador do real e abandona, portanto, sua pretensão de ser documentadamente verossímil tal como a história, é que ele abre a possibilidade para ser de fato representativo. Assim,

embora seja verdade que uma das funções da ficção, misturada com a história, é liberar retrospectivamente certas possibilidades não realizadas do passado histórico, é por meio de seu caráter quase histórico que a própria ficção pode exercer a posteriori sua função libertadora. O quase passado da ficção torna-se assim o detector dos possíveis escondidos no passado efetivo (RICOEUR, 2010, p.327, grifos no original).

Reconhecemos desse modo a relevância para a História de uma obra literária declaradamente ficcional por ela oferecer possibilidades outras de se "ler" o passado. No caso específico de Um novo animal na floresta e de seu autor, que era cronista, cuja escrita por definição mistura recortes da realidade com inventividade, movimento mantido por José Carlos no romance, procuramos privilegiar o entrecruzamento e a tensão entre o real e o imaginário presente na obra.

\section{Um novo animal na floresta - a narrativa}

Publicado pela editora Codreci, em 1981, Um novo animal na floresta tem 127 páginas e é dividido em um Prólogo e 34 capítulos. O mote da narrativa gira em torno de um episódio no qual a personagem, ao saber que sua amiga, a atriz Leila Diniz, hospedava um "refugiado político", embora ela mesma fosse "muito visada" pela polícia política, resolve abrigar o fugitivo em seu apartamento. A partir disso, Carlinhos narra a sua relação com o "refugiado" e o medo que sentia de ser enquadrado na Lei de Segurança Nacional por acolher um "terrorista".

O narrador privilegia aspectos subjetivos do protagonista - medos, ambições e concepções políticas - e a trama se desenvolve na medida em que busca situar o leitor no contexto político e cultural daquele período em que a Lei de Segurança Nacional parecia ter se tornado um norteador 
das relações pessoais. Como ambientação para a narrativa destaca-se a zona sul carioca, em especial, os bares Antonio's e o Veloso, e o apartamento do cronista, no bairro do Leblon.

No decorrer do romance é apresentada uma galeria de personagens - a "fauna ipanemenha" e seus dramas políticos existenciais, como a adesão ou não à guerrilha urbana. Mas na trama, Carlinhos não se relaciona apenas com esquerdistas. A partir da metade da obra aparece a descrição da relação de amizade estabelecida entre ele, apresentado como "cronista de renome", e um comandante da Marinha, ex-aluno da Escola Superior de Guerra (ESG).

Por fim, no último capítulo, intitulado Estes não voltarão, a personagem, ainda em retrospectiva, adere ao "desbunde" como forma de lidar com o seu passado. "Desbundar", no sentido empregado por Carlinhos, significava aderir, sobretudo, aos psicotrópicos, ao nascente movimento hippie, não se posicionar politicamente e se assumir como um "alienado". ${ }^{1}$ Alienação que, no entanto, aos olhos da ditadura não deixava de ser um movimento de resistência por afrontar os padrões morais propagados pelo regime.

Um novo animal na floresta é uma obra, como tantas outras entre o final da década de 1970 e início dos anos 80 , que veio à público "quando se iniciou o processo de abertura e os exilados voltaram para casa", momento histórico em que "uma farta literatura de denúncia invadiu as prateleiras das livrarias". Foi por meio dessa literatura que muitos se depararam "pela primeira vez com o horror que até então era apenas sussurrado em conversas de estudantes e militantes de esquerda" (DALCASTAGNÉ, 1996, p.15-16).

José Carlos Oliveira é um observador da sua época. É jornalista e cronista em um tempo em que a liberdade para esse tipo de registro enfrentou censura e vigilância constantes. Como muitos de sua geração (os escritores que vivenciaram a truculência do período dos governos militares para com a produção artística e literária), Oliveira dedicou-se à escrever romances.

Há, atualmente, respeitável produção memorialística sobre os acontecimentos circunscritos entre os anos de 1964 e 1985 no Brasil, em diferentes formas: entrevistas, diários, autobiografias, compilações de textos literários, romances, coletâneas editoriais, dentre outros.

A obra de Lucileide Costa Cardoso (2012, p.17), por exemplo, partindo do pressuposto de que "a memória histórica, assim como a ideologia, pode ser manipulada de acordo com as correlações de forças e interesses das classes num determinado momento histórico", analisa "doze livros de memória de caráter autobiográfico" que, segundo a autora, exercem a "função de legitimar, no presente, a memória histórica que se pretendeu dominante no período". As obras selecionadas pela autora, como ela própria reconheceu, são escritos individuais inscritos na memória coletiva. Quando

\footnotetext{
1 Já para o historiador Daniel Aarão Reis (apud KUSHNIR, 2007, s/p.) o termo desbundado "foi uma palavra inventada pelos caras 'duros' de vanguarda que, assim, se referiam desprezivelmente a todos que não viam com bons olhos a aventura das esquerdas armadas. Depois, passou a se referir especificamente às pessoas que cediam diante da tortura. Mais tarde, o termo tornou-se um genérico, designando, ambiguamente, seja os que eram contra a luta armada, desqualificando-os, seja os que cediam diante da tortura. Enfim, trata-se de um termo carregado de sentido pejorativo, e deve ser usado com muito cuidado. Em tempo: os torturadores gostavam muito de utilizá-lo".
} 
aborda o relato memorialístico da confessa esquerda, ou seja, daqueles que foram derrotados nos acontecimentos históricos, a autora afirma que eles, em seus relatos, "mesclam o desejo de testemunho com o exercício da crítica histórica" (CARDOSO, 2012, p.137).

O autor ainda fala de escritos tomados como a memória de personagens que se colocaram abertamente (ou claramente) como "opositores do regime que se implantou no país a partir de 64". Nesse sentido, as construções literárias das quais a autora lança mão diferem-se fundamentalmente do autor sobre o qual nos debruçamos neste artigo, na medida em que José Carlos Oliveira nunca se opôs diretamente aos governos militares.

Embora distintas, em relação à atuação confessa das personagens, as análises de Lucileide Cardoso e a que nós propomos guarda similaridades, no sentido de que

o confronto constante entre o 'eu' do passado e o 'eu' do presente assumem, nas narrativas, configurações ideológicas que não se restringem a contar apenas a experiência vivida [...], mas então imbuídas de uma perspectiva de reavaliação do passado que permite delinear novos projetos que ganham sentido na luta para transformação da sociedade (CARDOSO, 2012, p.138).

Outra diferenciação entre a abordagem de Cardoso e a nossa é que a autora trata de obras produzidas e escritas depois dos fatos e, no nosso caso, consideramos escritas no calor dos acontecimentos. No romance, a personagem Carlinhos de Oliveira enfrenta o desafio de explicar, a si mesmo e aos outros, porque não aderiu a luta armada.

Concordamos com Cardoso quanto ao fato de que quando um autor exerce a escritura de um texto em que propõe revelar suas lembranças, fatores sociais, o vivido, as impressões do grupo do qual ele faz parte, com o qual ele dialoga, o contexto que integra, como maior ou menor consciência, emergem na produção.

Da diversidade de produções memorialísticas ambientadas nos governos militares brasileiros, uma das abordagens mais recentes é aquela que faz uso de narrativas literárias.

As fontes literárias, ainda pouco presentes na produção historiográfica brasileira, segundo Virgínia Camilotti e Márcia Naxara (2009, p.28), constituem-se de "percepções, representações, figurações, por meio das quais se buscam os movimentos de instituição de imaginários e da própria temporalidade enquanto tal".

Não desconhecemos o debate sobre o status do romance na produção histórica. Há adeptos do uso do romances enquanto fontes passíveis de serem acionadas para construção de explicações 
globalizantes sobre o período histórico em que o livro foi escrito e sobre o seu autor. No outro extremo, existe uma consolidada corrente que nega o aspecto social da obra. Como criticado por Fontius (2002), estes pesquisadores, a maioria críticos literários, acreditam que a literatura só pode ser analisada por meio de parâmetros estéticos, pois os autores/artistas têm total autonomia na sua criação. Desta forma, os textos literários, como qualquer outra obra de arte, devem ser descolados do contexto social, da sua temporalidade, do espaço, da biografia do autor e do público ao qual foi destinado. A primeira vertente já foi defendida por historiadores conhecidos e a segunda está hoje em voga na historiografia em nome de uma nova geração de pesquisadores afinados com a crítica literária (FONTIUS, 2002; VÉSCIO, 1999).

Neste texto não nos colocamos em nenhum dos dois lados, uma vez que não pretendemos analisar o romance que selecionamos como se ele pudesse explicar o período dos governos militares, tampouco a partir de aspectos estéticos. A ideia é analisar a obra por dentro e perceber como a personagem do romance, as cenas que se sobrepõem e as muitas vozes revelam uma maneira peculiar de apropriação de mundo, de reflexão histórica. Sobre o assunto, concordamos com Antônio Candido (2000, p. 4):

\footnotetext{
Hoje sabemos que a integridade da obra não permite adotar nenhuma dessas visões dissociadas; e que só a podemos entender fundindo texto e contexto numa interpretação dialeticamente íntegra, em que tanto o velho ponto de vista que explicava pelos fatores externos, quanto o outro, norteado pela convicção de que a estrutura é virtualmente independente, se combinam como momentos necessários do processo interpretativo. Sabemos, ainda, que o externo (no caso, o social) importa, não como causa, nem como significado, mas como elemento que desempenha um certo papel na constituição da estrutura, tornando-se portanto, interno.
}

Cardoso (2012, p.139) vê os romances de Fernando Gabeira e Alfredo Sirkis como forma de embate com o autoritarismo e afirma: "Nesses escritores, imaginário e real se interpretam no labirinto da memória".

José Carlos Oliveira é um escritor oriundo dos meios de comunicação, assim como Fernando Gabeira, Alfredo Sirkis, Antônio Callado, Carlos Heitor Cony, Ignácio de Loyola Brandão, Fernando Gabeira, Antônio Torres, Ivan Ângelo e de vários outros, já que no período dos governos militares foi profícua a produção literária de profissionais ligados à imprensa. Alguns deles já foram objeto de trabalhos da academia. 
Geaneliza Pimentel (2012, p.45), ao estudar a produção de Antônio Callado e Jorge Andrade, por exemplo, conclui que "essa resistência se manifesta nos personagens através da luta que travam contra seus inimigos em defesa de seu patrimônio cultural, bem como valores na comunidade em que vivem". Vera Vieira (2011, p.15), para dar outro exemplo, afirma que escrever literatura foi a forma encontrada por Loyola Brandão para "sobreviver, criticar e resistir aos anos repressivos". Nas palavras do escritor, o ato da escrita era "dor e sofrimento, mas também o exercício contínuo da indignação, a maneira de lutar, desabafar, resistir, informar ao futuro o que estava se passando". "Na época", confessa Loyola Brandão, "escrever nos fazia sentir participantes e ativos".

De modo semelhante à outros escritores de romance do período, na narrativa ficcional que selecionamos para esse artigo, Um novo animal na floresta, fica evidente o desejo de rememoração do autor, a vontade de exorcizar os fantasmas do passado recente, de pensar sobre si mesmo num contexto de ausência de liberdade para a publicação, de confrontar os fatos históricos por meio da escrita ficcional. Assim, a narrativa literária foi, para muitos, forma de testemunhar o autoritarismo e com ele se relacionar.

\section{O projeto de Um novo animal na floresta}

O projeto para escrever o Um novo animal na floresta apareceu no diário de José Carlos Oliveira pela primeira vez em 5 de dezembro de 1980, ocasião em que ele manifestou a vontade de falar sobre a guerrilha.

Em 3 de janeiro de 1981, José Carlos apontou novamente em seu diário a intenção de escrever pelo menos dois livros naquele ano. Mas, no dia 15 do mesmo mês ele confessa como estava confuso diante dos papéis que deveria manipular, possivelmente arquivos, textos com a mesma temática proposta para o livro, mas que já tinham sido publicados como crônicas no Jornal do Brasil nos anos de 1978 e 1979: "Não há estrutura de romance (livro), é preciso inventar tudo, desconsiderar o já escrito, escrever de novo como se fosse uma tarefa a frio, um calculado bestseller" (TERCIO, 2005, p.258).

Se Oliveira, em 15 de janeiro, submerso na confusão de seus papéis, intenta reescrever, ou melhor, "inventar tudo" para que o livro assuma a estrutura de bestseller, dois dias depois (17 de janeiro) ele se contradiz ao escrever que "Um novo animal na floresta é um depoimento, uma golfada de recordações que sobem à consciência e se despejam na claridade do dia" (TERCIO, 2005, p.261). A obra foi planejada como invenção, como calculado sucesso editorial ou como depoimento, um "vômito de recordação"? O próprio autor parece equalizar essas dúvidas ao afirmar 
ainda em 17 de janeiro de 1981: "Vou reescrever sem reinventar. Simplesmente será uma tarefa fria, sem ênfase, sem grandes esperanças. [...] A julgar pelos leitores, é muitíssimo importante, não há dúvida que jornalisticamente não haveria assunto mais oportuno e instrutivo" (TERCIO, 2005, p.261). Oportuno, certamente porque naquela ocasião, em virtude da Lei da Anistia em vigor há dois anos, obras de memória sobre as ações da guerrilha começavam a surgir ${ }^{2}$ - com sucesso de vendas e repercussão - como atestam os livros O que é isso companheiro? de Fernando Gabeira e Em câmara lenta de Renato Tapajós, ambos publicados em 1979 e Os Carbonários - memórias da guerrilha perdida, de Alfredo Sirkis, lançado em 1980. Além de oportuno, o assunto do livro era também instrutivo, por tratar-se de uma temática que, se ainda hoje requer mais estudos, naquele momento histórico emergia como algo que tinha a necessidade de ser divulgado, dada a denúncia da prática da tortura e a constatação da censura que precedera aqueles anos.

Nesse mesmo dia, 17 de janeiro de 1981, José Carlos revela seu desejo de escrever o livro com os mesmos "efeitos de temporalidade" presentes na narrativa de Os miseráveis. O clássico romance de Victor Hugo teria, ainda de acordo com ele, duas visões do real narrado:

\begin{abstract}
uma cósmica, como se estivesse afastado 100 anos à frente (sem contradição) ou situado numa estrela distante. A outra visão é de memorialistas, frisando a data (outro tipo de distanciamento) em que escreveu, o que torna mais verossímeis os episódios, alguns francamente inacreditáveis, porém sem exceção fascinantes. [...] Essa é uma técnica interessante que abre perspectivas para o folhetim de jornal, agora. Mas a outra, a cósmica, é que me interessa. [...] Posso descrever minha época como quem se dirige às pessoas que viverão daqui a 50 anos, quando eu estiver morto, e assim todos os meus contemporâneos, e quando a cidade e o mundo estarão transformados. É o ponto de observação ideal, a começar pelo fato de ser fictício: é quando a memória tem que ser necessariamente imaginação e vice-versa (TERCIO, 2005, p. 261, grifo nosso).
\end{abstract}

Aqui é possível dizer que José Carlos Oliveira não atingiu de forma satisfatória o seu objetivo de narrador onisciente que relata de forma "cósmica" os acontecimentos. Em Um novo animal na floresta o autor não realizou o salto estilístico necessário para justificar o abandono do "memorialismo". A incapacidade de "saltar" para outro patamar ficcional fica patente na entrada do diário datada de 18 de janeiro, registro em que ele escreveu que o romance precisava ser pensado

$2 \mathrm{Na}$ disputa pela memória do período, os militares acusam os "memorialistas de esquerda" de não terem cumprido com a Lei da Anistia. Isso porque, como aponta Martins Filho em artigo, segundo a perspectiva dos militares "depois da Lei da Anistia de 1979, qualquer esforço de trazer à lembrança o que efetivamente ocorreu na breve e brutal repressão aos grupos de esquerda brasileira (não só de esquerda, vale registrar) representaria uma violação ao princípio da Anistia. Conforme essa ótica, anistiar é zerar as contas e, portanto, esquecer" (MARTINS FILHO, 2003, p.179). 
a partir dessa problemática estilística e da necessidade de se desvencilhar urgentemente da crônica e dos vícios de copidesque. Entretanto, o autor registra no diário que o aborrecia reescrever o projeto do futuro livro, pois ele acreditava que por mais que tentasse, o resultado seria sempre a apresentação de "apenas um lado do objeto, um ângulo". E acrescenta: "Falta a luz do dia e das estrelas nessa narrativa. [...] Não vejo outra solução para essa coisa frenética, confusa, ignorante, que eu mesmo intitulei 'romance bastardo'” (TERCIO, 2005, p. 262-263).

Por fim, em 23 de janeiro, José Carlos, provavelmente cansado dos próprios conflitos e sem muitas perspectivas de mudança na estrutura narrativa ou no estilo de escritura a ser adotado, nos revela quem seriam os novos e os velhos animais dessa fabulação:

Não há outro jeito: tenho que reescrever NAF [Um novo animal na floresta], mas sem modificar grandes coisas. Tenho que reescrever e publicar, ou deixar publicável. NAF termina quando começa: o conceito "animal novo" na floresta é que abre perspectivas para a imaginação e a fabulação. $O$ animal novo: Gabeira, sobrevivente do terror, sujeito e objeto dele; Roniquito ${ }^{3}$, o Aspone; Vera Lúcia, mulher emancipada; Regina Duarte, Rita Lee; Chico Buarque, a solução comunista para o homem cordial; frei Betto, o monge operário; Lula, o metalúrgico sindicalista, apartidário; Juruna, o índio na sociedade civilizada. Os velhos animais: Paulo Mendes Campos, Ferreira Gullar, Roberto Carlos, cada qual frustrado à sua maneira, tendo que inventar uma pessoa íntegra em plena desintegração das personalidades, desintegração purificadora, regeneradora e necessária (TERCIO, 2005, p.267)

Assim, em meio à tensão entre uma escrita passional, fundamentada na memória (e no esquecimento) e guiada pela lembrança e o rigor racional, estilizante e voltado à tornar inteligível o passado narrado, Oliveira publicou Um novo animal na floresta. O livro dessa forma se configura como a narrativa na qual o autor apresentou aos seus leitores a sua visão da dicotomia ideológica e das opções políticas que se apresentavam aos brasileiros no período da ditadura militar.

3 Nota do organizador dos diários Jason Tércio (2005, p.267): "Atribui-se a Roniquito a invenção do neologismo Aspone, como se ele autodefiniu ao dizer o que fazia com Walter Clark na TV Globo - 'sou Assessor de Porra Nenhuma". 


\section{Das passeatas à guerrilha}

A narrativa de Um novo animal na floresta começa no ano de 1980, com nossa personagem, Carlinhos, no bar Antonio's a refletir sobre as pessoas que frequentavam o local e não estavam mais lá:

[...] Onde andará quem por aqui andava quando por aqui andávamos? Decerto não morremos na guerrilha urbana; mas se nos sentimos sobreviventes, qual foi o desastre de que escapamos? Ora, para decifrar essa charada, é melhor recuperar aqueles dias. É melhor que os sobreviventes retrocedam ao tempo em que eram viventes, e passem a viver com ênfase aquela vida que viviam em surdina. Pois não é com saudade, e sim com anzol, que se pesca hoje o peixe que nos escapuliu ontem (OLIVEIRA, 1981, p.13).

Carlinhos, para responder a pergunta "qual foi o desastre de que escapamos?", se propõe a retroceder - rememorar? - cerca de 10 anos entre o momento de redação do romance (presente) e o acontecido (passado) para, ao revisitar alguns eventos que foram importantes para ele, e para o país, formular uma resposta ao futuro (seu e da sociedade que começava a ser informada dos porões da ditadura). Em busca de refletir sobre como e por que algumas pessoas, como ele mesmo, sobreviveram ao regime militar e passaram à margem da guerrilha, a personagem começa a passar o "passado a limpo".

Importante notar nesse percurso que o ato de rememorar exige muita atenção em relação ao presente, "pois não se trata somente de não se esquecer do passado, mas de agir sobre o presente. A fidelidade do passado, não sendo um fim em si, visa à transformação do presente" (GAGNEBIN, 2004, p.91). A personagem Carlinhos, e por hipótese também o autor, rememora porque o presente - 1981 - cobra dele a revisão de suas ações durante os anos de maior terror do regime instaurado em 1964.

Deste modo a personagem apresenta o bar que frequentava na narrativa: "um barco desvairado, procurando na escuridão o adunco desastre de gelo e ferragens, eis aí o Antonio's do período Al-5" (OLIVEIRA, 1981, p.12). Essa alegoria do bar como um barco à deriva também foi aplicada pela personagem ao Brasil que, como "Titanic tresloucado, suplicava aos mares a misericordiosa colisão do iceberg” (OLIVEIRA, 1981, p.13). Na citação, Carlinhos referia-se à confusão e instabilidade pessoal e política oriunda da publicação do Al-5, em dezembro de 1968.

É imerso no clima de tensão propiciado pelo Al-5 que Carlinhos rememorou alguns acontecimentos de 1968, como as manifestações estudantis. 
Encontramos, então, nossa personagem, Carlinhos, e um amigo, Jamil, como espectadores do confronto entre os estudantes e a polícia militar ocorrido na Avenida Rio Branco, "vista a caminho do Obelisco, por volta do meio-dia".

Bombas de gás lacrimogêneo disparadas de bazucas, cujo aspecto, por si, intimida, assoviam na claridade tropical, ocasionando a dispersão, pelas ruas transversais, desses atrevidos trombadinhas bem nutridos e mal-agradecidos, essas garotas e esses rapazes que ao entrarem na universidade ganharam do papai um fusca zerinho (OLIVEIRA, 1981, p.14).

Chamou-nos a atenção a descrição dos estudantes realizada por Carlinhos na citação anterior. Nela há uma apresentação nada romântica dos manifestantes, considerados "trombadinhas atrevidos e bem nutridos" - uma oposição aos "trombadinhas convencionais", esses sim provavelmente mal nutridos. Além disso, os estudantes são caracterizados como pessoas "malagradecidas", pois embora tenham sido premiados pela família com um carro pelo feito de ingressarem na universidade, estavam ali lutando contra, na verdade, a própria classe de origem.

Em flagrante contraste com o perfil socioeconômico dos manifestantes, foram apresentados os policiais que, "oriundos de camadas populares", lá estavam "lutando contra filhos ricos em defesa de pais milionários". Esses soldados "montam belíssimos cavalos que vivem melhor do que seus próprios filhos, e não são compreendidos por ninguém. Foram compelidos à luta pela necessidade camuflada em dever" (OLIVEIRA, 1981, p.15). Importante notar que a construção da imagem do soldado é o de pobre, cuja existência precária é acentuada pela comparação entre a condição de vida dos seus filhos e os animais que montam. Pobres homens em belíssimos cavalos que estavam ali por uma necessidade: cumprir ordens emitidas por superiores, esses sim, imbuídos de uma ideologia anticomunista e nacionalista.

A apresentação do movimento estudantil realizada por Carlinhos em Um novo animal na floresta é diferente daquela verificada nas crônicas que José Carlos Oliveira publicou no Jornal do Brasil. Nas crônicas os estudantes são idealizados como o futuro da nação e as manifestações que organizam são romanceadas, mesmo quando o autor as caracteriza como pouco eficazes. Enquanto as crônicas datam de 1968, lembramos que o romance foi escrito em 1981. Portanto o autor, José Carlos, pode ter, com a maturidade advinda do distanciamento temporal, realmente refeito sua opinião sobre o movimento estudantil, como pode apenas estar, por meio do conflito da personagem, apresentando as diferentes visões sociais sobre $o$ assunto.

Se Carlinhos nos oferece outra perspectiva do confronto estudantes versus PM, quem, na verdade, resume a situação é outra personagem, o Jamil, apresentada ao leitor como um homem de 
"cinquenta e poucos anos, boêmio, playboy conhecido na cidade, antigo secretário de Juscelino Kubitschek" e que morrerá meses depois de câncer:

\begin{abstract}
'O povo unido jamais será vencido' [...] Mas onde está o povo? Estou vendo um bando de crioulos montados a cavalo e um bando de alunas da PUC de cabelos espichados em rabo-de-cavalo. Os crioulos pobres defendem a propriedade, enquanto os garotões e cocotas arrebentam as vitrinas. E das janelas, os eleitores de Jânio Quadros se vingam da renúncia quebrando cabeças (OLIVEIRA, 1981, p.16).
\end{abstract}

A visão da personagem, mais uma vez, afirma a ideia de que o período dos governos militares foi de extrema confusão e multiplicidade ideológica. O discurso de Jamil também registra, além da batalha política ideológica, as marcas econômicas, sociais e raciais dos partícipes do confronto. Estão ali na vanguarda da opressão o grupo racial e a classe social - os criolos pobres historicamente oprimidos no Brasil em duelo contra estudantes de uma prestigiada universidade tradicionalmente frequentada pela juventude de classe média. Enquanto isso um terceiro grupo, os órfãos ressentidos da renúncia de Jânio Quadros, completam o trágico quadro atirando objetos nos polícias, possivelmente, mas sem se envolverem diretamente no confronto.

O romance prossegue com a personagem Jamil conversando sobre como se sente ao perceber que os conflitos entre a polícia e os estudantes eram carentes de propósito. Isso tanto do lado da situação que dava aos estudantes importância política demasiada, tanto do lado dos estudantes manifestantes que se arvoravam a enfrentar as forças policiais armadas:

Quem são os idiotas? Quem permitiu que as coisas chegassem a esse ponto. Esse ponto é aquilo ali: as viaturas da polícia civil, camionetas listradas em branco e preto, que deslizam nas calçadas em apoio à cavalaria [...]. Daqui a pouco eles [os órgãos de repressão] fabricam um cadáver, se já não fabricaram. É só o que está faltando nesta complicação: um cadáver. Depois que esse defunto for enterrado, no decorrer de uma trégua, não haverá mais licença para reuniões estudantis, seja lá onde for. E consequentemente os jovens entrarão na clandestinidade. Eu não lhe disse que são todos uns idiotas? (OLIVEIRA, 1981, p.17). 
O cadáver, o secundarista Edson Luiz, realmente existiu. A morte do estudante no restaurante Calabouço causou comoção nacional e impulsionou diferentes manifestações estudantis por todo o Brasil. A clandestinidade do movimento estudantil e a truculência com que foram tratados jovens e adolescentes contribuiu para a opção pela guerrilha de considerável parcela dos estudantes antes afiliados à UNE - União Nacional dos Estudantes.

No mesmo dia em que os jornais publicaram o obituário de Jamil, foi divulgado um assalto praticado pelos "infantes do MR-8" à rede de lojas de departamentos "Sears". Carlinhos, ao ler a notícia, registrou que os assaltantes foram gentis com as vendedoras e disseram que não "Ihes fariam mal, pois estavam lutando contra o capitalismo internacional e não contra humildes mulheres do povo. Eles também escreveram na parede os slogans do movimento [...] e saíram gritando 'abaixo a Ditadura!'. Uma das vendedoras teria dito que os assaltantes "eram jovens e bonitos, estavam alegres, pareciam participar de uma festa" (OLIVEIRA, 1981, p.19). Mas, registrou Carlinhos, da perspectiva confortável de quem revisa o passado: a ação da "guerrilha urbana em sua manifestação primitiva e desordenada, era apenas o sinal inequívoco de que marchávamos para dentro da noite interminável" (OLIVEIRA, 1981, p.19).

O ano de 1968 terminou, como todos sabemos, com um saldo negativo para as forças de resistência ao governo: a prisão de vários líderes estudantis no Congresso da UNE em Ibiúna afetou as manifestações, esvaziando-as (o chamado "descenso") e provocou o recuo do movimento estudantil (VENTURA, 2008). No limiar do mesmo ano foi promulgado o Al-5, "Ato que institucionalizou a tortura e outras formas de repressão" (REZENDE, 2001, p.91).

No vácuo do - terrível - ano que o antecedeu, 1969 foi marcado, sobretudo, pelo sequestro do embaixador estadunidense Charles Elbrick, ocorrido no mês de setembro. Ao saber do "rapto", Carlinhos, personagem que ainda não tinha se habituado a arrastar a "carcaça sob o peso de uma Ditadura", relata o clima pós-notícia no bar Antonio's:

Às oito horas da noite começaram a chegar os fregueses habituais. Tão diferente da noite do Al-5 - 13 de dezembro de 1968 [...]. Hoje aqui estão os que desapareceram naquela noite - a esquerda perseguida, a esquerda festiva, as grã-finas de esquerda, os bêbados que não têm partido mas também querem ver o circo pegar fogo. [...] Na verdade, a Ditadura está recolhida, tramando seu primeiro movimento - se aceita ou não as exigências dos terroristas - e nós estamos provisoriamente livres para discutir abertamente, ruidosamente, a situação política. Depois que o embaixador for libertado e os terroristas, identificados em plena ação, se dispersarem, a mais feroz perseguição será desencadeada contra eles, e a noite interminável descerá do Cruzeiro do Sul (OLIVEIRA, 1981, 23-4). 
Carlinhos, ao tipificar quem apareceu no Antonio's na noite do rapto do embaixador Elbick, salienta a variedade (perseguidos, festivos e grã-finas) de perfis políticos e sociais que compunham a genericamente chamada esquerda naquele momento. Mas a emergência desse animal político sedento por discutir publicamente, ainda que apenas por uma noite, a situação em que se encontrava o país só foi possível porque o governo, pego de surpresa pela ação dos guerrilheiros, planejava estratégias, reposicionava os órgãos e agentes da repressão para responder à guerrilha urbana.

Como atesta uma vasta historiografia sobre o período dos governos militares, o sequestro do embaixador norte-americano foi para muitos a façanha mais extraordinária das ações de contestação ao regime. Empreendida pela Dissidência da Guanabara (que logo passaria a utilizar o nome de MR-8) e pela Ação Libertadora Nacional (ALN), organização liderada pelo ex-deputado Carlos Marighella, a ação repercutiu por furar o bloqueio imposto pela censura aos veículos de comunicação, condição essa, entre outras, realizada pelos sequestradores para libertar o embaixador.

Após tamanha afronta, o regime respondeu com a reformulação da Lei de Segurança Nacional (LSN) tornando-a muito mais dura, inclusive por prever aos seus infratores penas como a prisão perpétua e a morte. Essa reestruturação dos mecanismos de repressão e da polícia política levada a cabo pelo governo após o ano de 1968

\footnotetext{
foram essenciais na derrota das organizações de luta armada. No entanto, é preciso lembrar que o elemento essencial na reestruturação da polícia política na derrota foi a tortura. A eficiência da repressão dependeu sempre e fundamentalmente deste recurso. Outro elemento fundamental que explica a derrota das organizações de vanguarda foi o seu isolamento em relação à sociedade, em parte porque elas acreditavam que 'numa primeira fase' este isolamento era mesmo necessário, mas, sobretudo, porque a sociedade jamais se identificou com o seu projeto político (ROLLEMBERG, 2006, p.10).
}

Quanto ao episódio do sequestro do embaixador, Carlinhos dizia saber "de certeza insegura" quem estava mantendo Elbrick em cárcere: Fernando Gabeira e os "audazes garotões do MR-8". Gabeira tinha sido jornalista no Jornal do Brasil e "fazia a ligação (redigia textos) entre o Departamento de Pesquisa e o Caderno B", onde Carlinhos publicava suas crônicas (OLIVEIRA, 1981, p.25). Além disso, Carlinhos nos apresenta Gabeira como sendo seu "vizinho no Edifício Gaivota, Rua João Lira 32", morando no segundo andar, apartamento 201, enquanto o cronista 
residia no primeiro andar, "apê" 102. Como vizinhos e colegas de redação, os dois jornalistas desenvolveram uma relação de coleguismo que se manifestava em almoços frequentes e no empréstimo mútuo dos óculos de grau. Quando Gabeira desapareceu, ou melhor, entrou na clandestinidade, Carlinhos nos diz que "seus óculos estavam enganchados no meu nariz" (OLIVEIRA, 1981, p.25).

A "captura" do embaixador Elbrick durou cerca de três dias e culminou com a soltura dele após o governo ceder às exigências dos "terroristas", expressas em um manifesto lido em cadeia nacional de rádio e televisão. Entre as condições impostas pelos sequestradores estava, além da divulgação do manifesto que denunciava a prisão e tortura de opositores ao regime, a libertação de 15 prisioneiros, entre líderes do movimento estudantil e figuras de nome da esquerda/resistência que, banidos do país, foram transportados e recebidos no México como asilados políticos. O manifesto terminava com a seguinte advertência direcionada aos agentes de repressão: "não vamos aceitar a continuação dessa prática odiosa. Estamos dando o último aviso. Quem prosseguir torturando, espancando e matando, ponha as barbas de molho. Agora é olho por olho, dente por dente". ${ }^{4} \mathrm{~A}$ ditadura, comandada pela Junta Militar que governava no lugar do convalescente Costa e Silva, respondeu ao achincalhe imposto pelos terroristas à altura e a noite, parafraseando Carlinhos, desceu do Cruzeiro do Sul.

Para Marcelo Ridenti, uma versão mais rígida da Lei de Segurança Nacional entrou em vigor imediatamente após o desfecho do caso do embaixador e uma nova Constituição, "imposta" em outubro, foi aprovada para legalizar e legitimar as arbitrariedades dos órgãos repressores. A maioria dos envolvidos no sequestro foi presa e torturada e, dois deles, assassinados. ${ }^{5}$ Esse também foi o destino de Carlos Marighella, o principal líder da ALN, morto em 4 de novembro em São Paulo. Nesse ponto, já no fim de 1969, começou a queda da incipiente esquerda armada. "Fechava-se tragicamente para os guerrilheiros 0 ano em que o país mergulhou nas trevas do obscurantismo político, cuja sobrevivência seria garantida nos anos seguintes pela força e pelo 'milagre econômico"' (RIDENTI, 1997, p.25).

Todos esses acontecimentos marcaram muito Carlinhos. A personagem acredita que o final do ano de 1969 significou o início do que ele chamou de noite interminável, metáfora adequada para ilustrar o estado de ânimo das pessoas a sua volta, a confusão psicológica que se apoderou dele e o pânico de ser enquadrado pela Lei de Segurança Nacional.

4 O Manifesto da ALN e MR-8 se encontra em anexo no livro de Reis Filho (1997).

5 Virgilio Gomes da Silva, codinome "Jonas", representante da ALN e comandante da operação, chegou à cadeia em 29 de setembro de 1969 e foi morto no dia seguinte. Já Joaquim Câmara Ferreira, o "Toledo", também membro da ALN, foi preso no dia 24 de outubro de 1970 e morreu no mesmo dia durante sessão de tortura. (GORENDER, 1987). 
Aqui o medo de Carlinhos, aliás, normal se lembrarmos que ele é um cronista escrevendo sobre cotidiano em um período de ditadura, começou a se transformar em pânico em virtude dos acontecimentos que ele vivenciou a partir e em decorrência do sequestro do embaixador pelo MR-8.

\section{Tempo de aflição...}

Algum tempo depois do sequestro, mas sem especificar exatamente quando, Carlinhos encontrou no bar Veloso o professor Kurt, descrito como "biólogo, economista, faixa preta de judô, 'garotão briguento'", mas possuidor de "agudo senso de lealdade e instinto de solidariedade que só se orienta para as pessoas e as causas corretas" (OLIVEIRA, 1981, p.27). Kurt contou para Carlinhos "alguns lances" da soltura do embaixador, como a perseguição emparelhada dos agentes da repressão aos sequestradores pelas ruas da zona sul, ambos os grupos com armas em punho e dispondo de granadas. Na oportunidade o professor também confidenciou a Carlinhos que a atriz Leila Diniz estaria guardando uma pessoa, alguém envolvido no sequestro do embaixador. No entanto, ainda segundo Kurt, o apartamento de Leila não era um lugar seguro, porque a própria atriz tinha problemas com a repressão: "Querem destruí-la. Querem impedir que continue na televisão, mesmo como teleatriz. Querem forçá-la a calar a boca e querem impedir que siga ganhando a vida no trabalho honrado" (OLIVEIRA, 1981, p.29).

Leila Diniz era uma mulher "vigiada" pelos órgãos de repressão por seu comportamento liberal para os padrões conservadores da época. Por isso "foi considerada subversiva e quase foi presa pela ditadura militar, por uma atitude ambiguamente classificada entre os campos da moral e da política" (GOLDENBERG, 1994, p.451). Diante da conjuntura desfavorável, tanto para Leila quanto para o "subversivo", era imperioso que outro esconderijo surgisse, mas "para onde irá o refugiado?". 6

O dito refugiado da narrativa, o Celso, ao que tudo indica, conforme Tércio (1999), é uma referência ao jornalista Francisco Nelson de Oliveira, o Chico Nelson. Na ocasião do sequestro de Elbrick, Chico Nelson tinha sido incumbido de escrever uma reportagem sobre o tema para a revista O Cruzeiro. Após o embaixador ser solto, Nelson recebeu a instrução do chefe de reportagem para que fosse até a casa do cativeiro porque a polícia tinha encontrado na garagem a Kombi usada no sequestro.

Era uma Kombi verde. Nelson tinha uma Kombi verde, comprada por ele para transportar papel, tinta, panfletos, quase sempre material da "gráfica" do MR-8, sediada no mesmo endereço

6 Interessante notar que há um descompasso temporal entre a narrativa de Um novo animal... e o biografo de José Carlos, Jason Tércio. De acordo com esse último quem abrigou primeiro Chico Nelson teria sido o cronista e não Leila Diniz. (TÉRCIO, 1999). 
que serviu de cárcere para Elbrick. Embora Nelson tivesse emprestado seu carro para o MR-8, não sabia que ele estava envolvido no sequestro do embaixador. Foi assim, "a trabalho", que o jornalista descobriu que o veículo utilizado no sequestro era o dele e, embora não estivesse envolvido diretamente em nenhuma das etapas da captura do embaixador, com certeza seria procurado e, no mínimo, condenado como cúmplice. Nelson entrou na clandestinidade naquele mesmo dia, ocasião em que encontrou abrigo na casa de Leila Diniz.

Em Um Novo Animal na Floresta, Carlinhos afirma que quem o convenceu a abrigar o refugiado em seu apartamento, naquele mesmo prédio onde um dia tinha morado Fernando Gabeira, foi sua companheira Maria, "16 anos e alguns abismos" mais nova do que ele.

Enquanto pensava na possibilidade de abrigar um fugitivo é interessante notar que a personagem se apresenta, o que até então não tinha sido feito de forma tão ostensiva. A citação a seguir é longa, mas fundamental para compreender o Carlinhos de Um Novo Animal na Floresta, bem como para problematizar a relação entre a personagem e o autor, entre o status individual e 0 coletivo da memória. Disse de si mesmo, então, Carlinhos:

Ao contrário dessas crianças de vinte anos, que são contra o Governo entre outros motivos porque o governo nutre desconfiança por quem quer que nestes dias tenha vinte anos, sou um veterano existente, um controvertido figurante na tragicomédia antes sofrida que interpretada pelos intelectuais cariocas, desde a virada brutal da mesa de pôquer pelos façanhudos de 1968 [...]. Sou socialista simpatizante (minha inscrição está - ou esteve - nos arquivos do Partido Socialista Brasileiro, já varrido de cena) trotskista por afinidade, surrealista por temperamento, anarquista por indisciplina de berço, boêmio por amor à vagabundagem, agregado à elite pensante por acaso [...] As pessoas estão acostumadas a encontrar entrelaçados o meu ser peripatético e o patético espetáculo da atualidade. Escrevo o que vou vivendo, o que vamos vendo e sofrendo. Tenho um compromisso: dizer a verdade do indivíduo tal (José Carlos Oliveira), na circunstância tal, em confronto com o fenômeno xis. - Carlinhos Oliveira pode fazer isso? Carlinhos Oliveira não sou eu (ao menos não totalmente), e sim o personagem inventado conjuntamente por mim e pelo público. Represento esse personagem dia e noite e em toda parte, mas quem escreve, e quem leva a vida a sério, se assina José Carlos. José Carlos tem projetos grandiosos para um futuro mais ou menos distante, quando se tornará romancista-anacoreta; Carlinhos vive o momento, e é irresponsável (OLIVEIRA, 1981, p.31-2). 
Foi Carlinhos, "o irresponsável", e não necessariamente sóbrio na mesa do bar, alguém que não estava muito interessado em saber quem era de fato o guerrilheiro, que decidiu pôr um colchão no quarto onde estavam os livros e mandar chamar o refugiado. Sim, pode ser por irresponsabilidade, por embriaguez, para agradar a jovem namorada ao seu lado ou ainda porque decidira flertar com a guerrilha que Carlinhos tomara aquela decisão. Porém, ao tomá-la ele certamente não imaginava que a presença de Celso resultaria em um profundo desequilíbrio emocional e psicológico.

A presença travestida de ausência de Celso no apartamento de Carlinhos, aos poucos, inseriu o cronista no universo, ao menos discursivo e simbólico, da resistência armada à ditadura. Assim, por meio da convivência com o "refugiado", o cronista aprendeu "pouco a pouco" a reconhecer os jargões da guerrilha urbana e os ambientes em que os mesmos podiam ser utilizados - "caiu... aparelho... 'a organização'", compreensão que, segundo ele, evitava problemas naqueles dias "de codinomes e múltiplas identidades" (OLIVEIRA, 1981, p.35).

Apesar do cotidiano dividido com um clandestino, Carlinhos não tinha as convicções políticas de todos aqueles jovens comprometidos em derrubar a ditadura. Esse fato ficou claro quando questionaram quem ele escolheria para presidente do país caso fosse forçado: o presidente Médici ou Carlos Marighela? Carlinhos respondeu: nenhum dos dois.

Esse tipo de postura da personagem é plasmada no próprio autor. Como Carlinhos, a personagem, José Carlos também, por vezes, fugia da dicotomia esquerda/direita ou opressão/resistência armada. Para ele, autodeclarado um amante das liberdades, qualquer grupo que propusesse ações ou realizasse discursos que tolhessem a liberdade individual em suas mais diversas esferas, ou seja, manifestações contrárias à democracia - tanto à esquerda como à direita - não contariam com o seu apoio.

Além do mais, tudo indica que José Carlos Oliveira, como Ihe era característico, desempenhava papéis contraditórios que acabavam por suscitar muitas dúvidas sobre suas escolhas políticas. Falta de posicionamento, motivado, talvez, por uma espécie de anarquismo existencial também encontrado na personagem, que provocou à época muita estranheza por parte de alguns intelectuais que o consideravam um cronista alienado, ou alguém que escolheu a via mais fácil: a incessante embriaguez.

Assim, em público, nos bares como Antonio's ou Veloso (nomes que o autor manteve no romance), frequentados tanto por esquerdistas quanto por militares, José Carlos, e igualmente Carlinhos na narrativa, assumia o papel de bêbado, comentarista de frivolidades. 
Segundo o biógrafo do autor, tal comportamento possivelmente explica-se pelo medo que o cronista tinha da prisão e tortura. ${ }^{7}$ Em relação à personagem sabemos que o medo da tortura era algo aterrador, praticamente doentio:

Eu não imagino a tortura, mas ela me imagina. Totalmente inventada pelo pavor em que tenho vivido, a cena se configura entre meus olhos vigilantes e a sonolência própria do ser - ou seja, na região do devaneio: o pau-de-arara, o choque elétrico, o telefone (série de palmadas brutais nas orelhas do infeliz até espirar sangue), o afogamento em balde de excrementos - tudo isso não é senão uma escatologia horizontal - a introdução do cassetete no ânus, e não se diz 'no cu' ninguém sabe por que; a ferida fechada para ser reaberta, outra vez fechada e outra vez esfolada, Horror (OLIVEIRA, 1981, p. 56).

A relação dos instrumentos e das práticas utilizadas pelos torturadores por Carlinhos demonstra a aviltante violência à qual os presos políticos eram submetidos em quartéis, bases áreas ou navais, e delegacias, em "porões" espalhados por todo o país. O suplício do corpo e da mente é o inimaginável, o irreal que, no entanto, foi utilizado em interrogatórios políticos e sessões de horror que, somente por imaginar, provocava alucinações em Carlinhos.

É nesse estado de devaneio, revelador sobre o sentimento de pânico instaurado em certos grupos sociais pela repressão, que Carlinhos formulou várias justificativas endereçadas aos seus torturadores, para usar se fosse preciso. Ele pensou em afirmar: "Dei guarita a um rapaz que diz chamar-se Celso e alega estar sendo perseguido por um aparato policial selvagem, tão clandestino, impiedoso e imprevisível quanto o próprio terrorismo urbano" (OLIVEIRA, 1981, p.56). Também pensou em falar:

\footnotetext{
- Queridos torturadores, parem com isso! Não me podem arrancar confissão alguma, pois nada tenho a confessar! Sei apenas que existe uma "Organização" que pode ser o MR-8 e pode não ser. O cidadão cujos testículos vocês querem extirpar, de nome ou codinome Celso, entrou na minha vida pela porta dos fundos, em cujo frontão está escrito: Solidariedade Humana! Mas prestem atenção: é a porta dos fundos! Entenderam? Assim como o cachorro entra na igreja porque encontrou a porta aberta, um guerrilheiro urbano entrou pelos fundos da minha consciência, a qual não tem
}

7 Nesses tempos nos quais não se sabia ao certo quem poderia ser um agente infiltrado, do governo ou dos grupos guerrilheiros, José Carlos era visto com relativa desconfiança por ambos os grupos. (TÉRCIO, 2005). 
trancas nem ferrolhos porque não se pode conceber uma solidariedade que a si mesma se impeça de exercer. Não sou culpado de coisa nenhuma, embora também não seja inocente (OLIVEIRA, 1981, p.56-7).

O pânico que se apossa de Carlinhos, o medo do horror que é a própria tortura que bestializa o humano, não cede aos argumentos do cronista. Ele sabe que ela, a sua sessão de punições, não é real, mas sabe também da possibilidade dela se tornar concreta. Quanto a isso, a mente fraturada que cede ao fantasma do torturador, não há o que fazer a não ser esperar que ela se recomponha.

\section{...E tempo de festa}

Os dias passaram. E Carlinhos se remeteu a eles como um "pesadelo permanente", do qual ele não acordava, mas que provocava uma angústia inexplicável e intensa.

A presença de Celso, "o homem da Kombi do sequestro do embaixador", assombrava Carlinhos, para quem o seu nome e endereço estavam ao alcance da repressão e poderiam ser descobertos, "junto com um gemido do pau-de-arara [...], ou uma golfada de sangue" (OLIVEIRA, 1981, p.106).

Em meio ao abrigo à Celso, o medo de ser descoberto e torturado, Carlinhos conheceu e se tornou amigo de um "Comandante", oficial da Marinha. Aqui mais uma vez é explicada a razão da desconfiança que muitos nutriam sobre a possibilidade de Carlinhos ser um agente do regime, já que ele, além de não ter sido preso, mantinha essa amizade pública com um comandante das Forças Armadas. Carlinhos, em tom de troça, fala que, ao anunciar no bar a presença do oficial em sua mesa, os "esquerdistas" do botequim mudaram de lugar. A reação deles a presença do comandante provoca no cronista estranheza, afinal, eram os "mesmos esquerdistas que antes paparicavam aqueles mesmos militares, quando estes obedeciam ao comando de Jango, 0 Presidente socialista na retórica, mas latifundiário feudal na inamovível realidade do sistema" (OLIVEIRA, 1981, p.112).

É justamente para esse amigo militar que Carlinhos exagera o papel de alcoólatra estereotipado. Ele age assim intencionalmente, como mecanismo de defesa para esconder o foragido político que abriga, fato que o Comandante não podia desconfiar.

Pouco tempo depois de chegar, o hóspede de Carlinhos se despede dele, desaparecendo da narrativa. Mas ter abrigado um foragido em sua casa e as notícias de conhecidos que tinham 
sucumbido à repressão, física e psicologicamente, continuam a desestabilizar a personagem, Carlinhos, de tal forma que quase o levam à internação em um manicômio.

Em Um novo animal na floresta a noção temporal é condensada de forma indiscriminada. Os eventos do dia a dia, na voz do narrador, recebem maior destaque que os anuais. O tempo é claramente subjetivo e os acontecimentos narrados seguem a lógica do não-linear, da sobreposição em detrimento da sucessão temporal clássica.

Diante da possibilidade e iminência de perder a razão, Carlinhos adota a boemia como resposta aos seus desvarios. Ele tenta, desse modo, enfrentar sua loucura agarrando-se ao que tem de mais concreto e certo na vida: os bares e o álcool. É nesse momento que surge uma personagem que representará na trama a saída definitiva de Carlinhos das trevas em busca do "desbunde": Gouveia.

Gouveia, identificado no romance como aquele que "faz música" apresenta à Carlinhos o universo hippie, composto por "filhos andarilhos, que não pretendem voltar à casa paterna" (OLIVEIRA, 1981, p.165). A opção da vida hippie significa, no imaginário da personagem, o fim da responsabilidade com o futuro, com a disciplina, com o desenvolvimento da sociedade e com o país.

Os hippies, ou "andarilhos", reuniam-se em um apartamento descrito por Carlinhos como um acampamento com "pequenas tendas de lona nos quartos e na sala", local em que não havia móveis, mas uma rede sob a qual tinha uma moringa. Os habitantes do acampamento eram pessoas que tocavam violão no quarto; três bebês nus que dormiam na sala sobre uma esteira, duas "mocinhas grávidas, nuas sob camisolões transparentes, e uma mocinha de microssaia e sem barriga" que comiam, agachadas em um canto, "frango assado com as mãos, num prato fundo de Iouça" (OLIVEIRA, 1981, p.165). Chamou-nos a atenção o fato de que a descrição do mundo hippie e do apartamento representa o descolamento da personagem da realidade e dos padrões até então aceitos de sociabilidade. Argumenta a personagem que a forma de viver daquelas pessoas era "quase uma vingança antropológica" ao padrão da família tradicional.

Nesse apartamento-acampamento, durante "um tapinha, e outro" em um baseado, Gouveia Ihe explicava o modus vivendi do grupo:

- Aqui é tudo limpeza, amizade. Tudo numa boa. A gente vive sem aquela sujeira da sociedade tecnológica. As meninas não tomam a pílula; se transam engravidam, deixam vir o bebê. A gente está aqui e amanhã pode estar em outro lugar. Outro dia pintou de irmos à Bahia. [...] A gente queimava um fuminho, comia um caranguejo, fazia serenata ao luar. Os "homi" apareceram de madrugada e levaram todo mundo pra cadeia. Pintou uma sujeira braba. Deram tanta porrada na gente! Rasparam a nossa cabeça alegando que 


\begin{abstract}
cabelo comprido dá piolho. "Está bem, dá piolho, e daí? Precisamos reconsiderar a questão do piolho. Se Deus dá o piolho a quem tem cabelo, é porque o piolho, tanto quanto o cabelo, está nos planos de Deus. Sacou essa?" Sacaram nada, bicho! Depois que eu fiz esse discurso, a barra ficou ainda mais violenta, a porrada comeu feio pra cima de "moi". E também nos deram banho de criolina. Sujeira pura! Sacanagem. Patifaria. Ditadura de merda (OLIVEIRA, 1981, p.166-7).
\end{abstract}

A explicação de Gouveia desenha um quadro no qual a dualidade, tal qual no barroco, é o elemento central representado, sobretudo, pela "limpeza" versus "sujeira". A limpeza da amizade, da liberdade de ir e vir, de fumar, comer e fazer serenata ao luar em oposição à sujeira da sociedade tecnológica, da ação policial, da "porrada", da ausência de moral, da "merda" da ditadura que, embora suja, promove a higienização do corpo. Nesse cenário, mais uma vez, se afirma o incômodo gerado pelos hippies ao regime e sua "utopia autoritária".

É preciso salientar que o modelo de existência expressado, sobretudo, corporalmente (roupas coloridas, acessórios artesanais, barbas e cabelos compridos) pelos adeptos da contracultura era considerado pelos governos militares um perigo à pátria. No entanto, o perigo dos costumes não foi visto como ameaça tão iminente como a guerrilha. Afinal, os membros do aparato repressivo separavam os que deviam ser eliminados daqueles que tinham chance de serem (re)integrados à sociedade por meio de ações pedagógicas. Foi comum, por exemplo, militares argumentarem que "os brasileiros eram "despreparados", não sabiam votar, [...] não possuíam, nem ao menos, noções básicas de higiene ou de civilidade urbana, sendo portanto necessário "educá-los" (FICO, 2011, p.7).

Gouveia prossegue explicando para Carlinhos que, mesmo depois que foi preso e posto em liberdade por meio de um habeas-corpus preventivo, a opção hippie Ihe garantiu a volta ao sossego e o fim dos traumas sofridos durante o período de reclusão: "pintou novamente aquela limpeza absoluta. Muito banho de mar, todo mundo nu, muita cannabis sativa pra sair daquele horror e entrar numa boa, muito ácido pra viajar pelas constelações multicores" (OLIVEIRA, 1981, 167).

Carlinhos, que também desejava sair do estado de pânico que estava desde o abrigo ao refugiado, viu na solução de Gouveia a possibilidade de outra vida, da vida errante que the foi ofertada pelo discurso do amigo.

Insistiu o amigo ao oferecer-Ihe um ácido: "Vai nessa?". E apresentou-lhe um ácido, um convite certo para a viagem alucinógena, e um vaga para o transporte que ia para a praia, viagem física. Carlinhos embarcou em ambas, e uma grande alegria o entonteceu. Ele estava, finalmente, nu e sem vergonha: "Aquele mundo de onde venho, de ferros que andam, já é coisa do passado" (OLIVEIRA, 1981, p.167). 
No passado ficaram o terror, a noite escura, a aflição, o presente é de desbunde, do amanhecer e, nas palavras da personagem, da "sinfonia dionisíaca que sobe do horizonte justamente com inumeráveis tons de azul e rosa" (OLIVEIRA, 1981, p.167).

\section{Considerações Finais}

Em Um novo animal na floresta, embora o autor José Carlos Oliveira se valha de acontecimentos históricos e de possíveis pessoas reais como inspiração, a trama não pode ser lida como relato fidedigno da história. Um novo animal na floresta não tem o compromisso de ser uma obra historiográfica, portanto, com metodologia e pressupostos teóricos que asseguram os padrões de verossimilhança. Mas, ainda assim, a narrativa faz referência ao real vivido e sentido, o que aponta para a relevância do uso de fontes variadas para a escritura da história.

No caso específico de Um Novo Animal na Floresta consideramos que o romance foi escrito por um autor preocupado em justificar para si e para o mundo o motivo que o levou a não aderir à guerrilha como forma de resistência à ditadura militar brasileira estabelecida em 1964. Nesse sentido, chamou-nos a atenção o fato da personagem se dedicar a rememorar seus encontros com diferentes pessoas em casas noturnas, sobretudo no bar Antonio's, tendo sempre como contexto a passagem de jovens do movimento estudantil para a guerrilha em contraponto a trajetória pessoal de Carlinhos (personagem), já trilhando o caminho da contracultura.

$\mathrm{Na}$ visão de Carlinhos, depois do acirramento da repressão, do desaparecimento de muitos conhecidos, do autoritarismo, das prisões e tortura, período representado na narrativa como "depois do Al-5", a única saída era a clandestinidade, a morte do cidadão, a guerrilha. Mas nossa personagem tinha pavor de sevícias físicas e não era muito afeito a se filiar a uma única ideologia. Ele preferiu a máquina de escrever às armas, e, apesar de ter abrigado um procurado pela polícia política, chegou a se arrepender e até entrou em pânico.

Assim, na impossibilidade tanto de agir diferente como de concordar com o que fez, restou a Carlinhos o desbunde, ou seja, a fuga proporcionada pelos entorpecentes, a promessa de liberdade da mente e do corpo ao associar-se à uma comunidade hippie, enfim, a opção por uma vida alternativa àquela na qual o terror era um sentimento preponderante. 


\section{Referências}

BRANDÃO, Ignácio de Loyola. Literatura e resistência. In: SOSNOWSKI, Saul, SCHWARTZ, Jorge (Org.). Brasil: o trânsito da memória. São Paulo: Edusp, 1994.p.177-183.

CAMILOTTI, Virgínia; NAXARA, Márcia Regina Capelari. História e Literatura: fontes literárias na produção historiográfica recente no Brasil. História: Questões e Debates. Curitiba, n.50, p.15-49, 2009.

CANDIDO, Antônio. Literatura e Sociedade: estudos de teoria e história literária. São Paulo: Queiroz, 2000.

CARDOSO, Lucileide. Criações da memória: defensores e críticos da ditadura (1964-1985). Cruz das Almas/BA: Ed. Universidade Federal do Recôncavo da Bahia, 2012.

DALCASTAGNÈ, Regina. O espaço da dor. Brasília: Ed. Universidade de Brasília, 1996.

FONTIUS, Martin. Imitação. In: LIMA, Luiz Costa. Teoria da Literatura em suas fontes. Rio de Janeiro: Civilização Brasileira, 2002. v. 1, p. 105-107.

FICO, Carlos. Regimes autoritários no Brasil republicano. Conferência realizada por ocasião das provas do Concurso Público de Provas e Títulos para o cargo de Professor Titular de História do Brasil da Universidade Federal do Rio de Janeiro, 2011.

GAGNEBIN, Jeanne. Memória, História, Testemunho. In: BRESCIANI, S.; NAXARA, M (Org.). Memória e (res)sentimento: Indagações sobre uma questão sensível. Campinas: Unicamp, 2004.

GOLDENBERG, Mirian. Leila Diniz: a arte de ser sem esconder o ser. Revista Estudos Feministas, Rio de Janeiro, v. 2, n.2, 1994.

GONRING, José Irmo. Penas de um Pavão: Autoficção e performance em José Carlos Oliveira. Revista Eletrônica de Estudos Literários, Vitória, s. 2, ano 8, n. 10, 2012.

GORENDER, Jacob. Combate nas trevas. A esquerda brasileira: das desilusões perdidas à luta armada. São Paulo: Ática, 1987.

KUSHNIR. Beatriz. Desbundar na TV: militares da VPR e seus arrependimentos públicos. In: SIMPÓSIO NACIONAL DE HISTÓRIA: História e multidisciplinaridade: territórios e deslocamentos: ANPUH, 24., 2007, São Leopoldo. Anais... São Leopoldo: Associação Nacional de História, 2007.

MARTINS FILHO, João Roberto. A guerra da memória: a ditadura militar nos depoimentos de militares e militantes. Varia História, Belo Horizonte, n.28, p. 178-201, 2003. 
OLIVEIRA. José Carlos. Um novo animal na floresta. Rio de Janeiro: Codreci, 1981.

REIS FILHO, Daniel Aarão et al. Versões e ficções: o sequestro da história. São Paulo: Fundação Perseu Abramo, 1997.

REZENDE, Maria José de. A ditadura militar no Brasil: repressão e pretensão de legitimidade 19641984. Londrina: EDUEL, 2001.

ROLLEMBERG, Denise. A ditadura civil-militar em tempo de radicalizações e barbárie. 1968-1974. In: MARTINHO, Francisco Carlos Palomanes (Org.). Democracia e ditadura no Brasil. Rio de Janeiro: Ed. Universidade Estadual do Rio de Janeiro, 2006. p. 141-152.

RIDENTI, Marcelo. Que História é essa? In: AARÃO, Daniel et al. Versões e ficções: o seqüestro da história. São Paulo: Fundação Perseu Abramo, 1997.

RICOEUR, Paul. Tempo e Narrativa: O tempo narrado. São Paulo: WMF Martins Fontes, 2010. v. 3.

PIMENTEL, Geaneliza. A memória presente: estudo da dramaturgia de Antônio Callado (A Cidade Assassinada) e Jorge Andrade (Pedreiras das Almas). 2012. Dissertação (Mestrado em Letras) Universidade Federal de Uberlândia, Uberlândia, 2012.

TÉRCIO, Jason (Org). Diário Selvagem. Rio de Janeiro: Civilização Brasileira, 2005.

TÉRCIO, Jason. Órfão da Tempestade. Rio de Janeiro: Objetiva, 1999.

VENTURA, Zuenir. 1968: O ano que não terminou. São Paulo: Planeta do Brasil, 2008.

VÉSCIO, Luiz Eugênio. Literatura e história: perspectivas e convergências. Bauru: Edusc, 1999.

VIEIRA, Vera Lúcia Silva. Ignácio de Loyola Brandão: memória e literatura, a escrita como exercício da indignação. 2011. Dissertação (Mestrado em Ciencias Sociais) - Faculdade de Ciências Humanas e Sociais, Franca, 2011.

Recebido em 10.03.2015 - aprovado em 10.11.2015 